\title{
A SUGGESTED MODEL FOR SUCCESSION PLANNING / CASE STUDY IN THE IRAQ MEDICAL CITY
}

\author{
Researcher: Atheer Tahseen Ali, Prof.Dr.Ghani D. Al -Zubaidi \\ Ministry of Health College of Business and Economics \\ Medical City University of Baghdad
}

DOI: $10.37648 / \mathrm{ijrssh} . v 10 \mathrm{i} 03.028$

Received: 10 ${ }^{\text {th }}$ June, 2020; Accepted: 15th July, 2020; Published: 05 ${ }^{\text {th }}$ August,2020

\begin{abstract}
This research aims to build a suggested model for succession planning for the purpose of preparing candidates for leadership positions and main jobs and building future leaders. the importance of this research is that it is one of the scarce Arab and Iraqi studies and research in this field, as it is one of the first researches that deals with a suggested model for succession planning to fittings the environment of Iraqi organizations. The research problem was represented by the absence of succession planning programs and the weak preparation of suitable candidates as replacements for the current leaders who occupy the leading and main positions in the Medical City Department, as the research sample included all department managers in the Iraq Medical City Department / General Administration, whose number is (8) eight department directors, and who have nominated (29) twenty-nine candidates for the succession planning program to fill the Administrative positions In the event of a vacancy in the future, and the researcher has adopted a case study method Because it collects more than one research method at one time, Data and information were collected using a succession planning model based on the matrix (traits performance), in addition to questions of personal interviews and observations during field coexistence and official documents obtained during field visits to the organization, and the researcher depend the arithmetic mean and the percentage for solving Candidates data, and Most prominent results the findings of the researcher is the possibility of applying the suggested model for succession planning in the Iraq Medical City Department / General Administration

keywords /Succession planning, Performance evaluation, traits evaluation, job behavior evaluation,(traits Performance) Matrix.
\end{abstract}

\section{1-INTRODUCTION}

The interest in succession planning has increased due to the presence of many important leadership job that cannot be vacancies in any way, and in order to avoid vacancy in these jobs, organizations must adopt succession planning programs in order to find the best available employees to replace the leaders or occupants of important jobs those who left Or they will leave the organization, and providing them in time to fill those jobs. In recent decades, global trends have become more interested in succession planning in health organizations because of their lack of application in these organizations, where many organizations suffer from many problems due to the lack of application of succession planning programs 
or Failure to apply them, and hence the idea of research that tried to build a proposed model for planning Succession to prepare future leaders, as the early implementationideally of succession planning leads to the sustainability of the organizations work and its continued success in an environment characterized by rapid change and Strong competition. The public administration in the Department of medical city, located in the capital, Baghdad, was chosen as the field of application, as the researchers adopted a model for succession planning using the matrix (traits- performance) as a research tool, and it was distributed to a intended sample of the directors of the department in the Public Administration / Physician Department of the City for the purpose of selecting candidates for the succession planning program to fill the positions of the departments in the event of their vacancy in the future.

\section{2- RESEARCH METHODOLOGY :}

\section{2-1 Problem statement}

The research problem can be summarized in the absence of applying the succession planning process, the weak preparation of suitable alternatives ready for job succession, and the lack of interest of the higher management in the research organization in the mechanism of implementing succession planning, and the weakness of early application of this process led to a defect in the leadership job, administrative and key positions in the public administration /medical city .

\section{2-2 Research question}

1) What is the level of adopting succession planning in the Medical City department for leadership, administrative, and key positions?

2) How are vacant positions in leadership, administrative, or vacant positions filled in the Medical City department?

3) What are the approved criteria for selecting department managers? Is there a database to nominate employees for leadership or key positions in the organization in which the research was conductedn!
4) Can a succession planning model be built for medical City?

\section{2-3 Objective of the study}

This research attempts to achieve a number of goals through the following points:

1) Knowing the succession planning that has been growing interest from writers and researchers over the past years for its contributions to the continuity of the work of the organizations and the sustainability of their success.

2) Diagnosing the reality of succession planning in the public administration / Medical City Department.

3) Building and developing a tool that helps the upper and middle departments to prepare suitable replacements to fill leadership and important positions in the organization in the event of vacancy for any reason, and this tool is the suggested model for succession planning.

\section{2-4 Research Method}

The case study method was chosen for its capabilities in combining more than one research method, as it relies on field coexistence and conducting personal interviews to present the questions on the sample that has been the case study and record the impressions that require them.

\section{2-5 Search tool}

The researchers used a suggested model for succession planning as a tool to collect data and information for the research sample and for candidates for career succession. This tool includes five sections:

1) The first section: Contains the demographic variables of the section managers of the research sample.

2) Section Two: Contains the demographic variables of the employees who are nominated for succession.

3) Section Three: It contains two evaluation forms according to two axes:

The candidate's performance evaluation axis and the candidate's traits/ job behavior axis

4) Section 4: Contains the section manager's comments regarding the employee's strengths and weaknesses or any other notes. 
(IJRSSH) 2020, Vol. No. 10, Issue No. III, Jul-Sep

5) Section Five: Matrix (traits - Performance) for the distribution of candidates for career succession based on the evaluation results, and It is a development of a(performance - culture) matrix ( Romanowski,2016:45).

\section{2-6Research society and Research Sample}

The general administration / Iraqmedical city department was chosen as a community to apply the research represented by its different departments, and the directors of these departments represent the research sample and they number (8) eight managers.

\section{3 - LITERATURE REVIEW :}

\section{3-1 the concept of Succession planning}

Succession planning can be defined as an organized process that involves identifying and preparing a potential successor to take on a new role, which means the need for a reliable and reproducible process (Barnett \& Davis, 2008:721) , Succession planning has also been defined according to the entrance to administrative development as a strategic and systematic effort to develop competencies for potential leaders through proposed learning experiences such as targeted training and educational training in order to occupy senior positions without favoritism, as consecutive planning works to perpetuate the organization by filling gaps Positions are with high performing people to ensure that each leadership level has an abundance of these people to benefit from, now and in the future (Adewale,et al.,2011:234) , As succession planning gives employees the opportunity to develop leadership skills that can be used in current staff positions and any future jobs (Galbraith \& Smith, 2011: 223), succession planning has also been defined as an organizational management tool used to ensure continuous performance in an organization by identifying key internal people for business activities over time (Hickey, 2002 :5) , Succession planning can be considered as a proactive attempt to make sure that there are leaders for the organization in the future by knowing how those jobs will be filled, when there are employees leaving the organization, whether their exit is planned or unplanned (Schmalzried \& fallon, 2007:169), It was also defined as the process of
e-ISSN: 2249-4642, p-ISSN: 2454-4671

ensuring the availability of qualified persons to occupy key management positions once positions are vacant (Mondy\&Martocchio ,2016 : 112), It was also defined as a deliberate and systematic effort by the organization to enhance leadership continuity in key positions, to develop and preserve intellectual and knowledge capital for the future, and to encourage individual progress (Al-Samman, $2012: 2$ ) , After reviewing these definitions, succession planning can be defined as a procedural definition for the purposes of the current research : it is process Determine leadership, major, or critical roles in the organization, and identifying distinguished individuals in the work as candidates for succession through their inclusion in the planning program to provide them with the necessary skills and expertise necessary to fill vacancies with the required quality and efficiency.

Succession planning can happen at two different times :

(Collins\&Collins,2007:322-323)

A- When jobs are vacant naturally within the organization due to retirement or resignation or any other reasons, the best person available to fill the vacant position is brought in.

B - When the employee develops and matures enough, a position is created to accommodate it, meaning finding opportunities for employees who have been fully prepared instead of waiting for vacancies suitable for them, as this option is the solution to ensure that these qualified and talented employees are not attracted by competing organizations .

\section{3-2 The importance of succession planning}

Succession planning is important in the process of preparing for the transfer of power and changing leaders, and that successful organizations do not consider succession planning a matter of substitution but rather consider it primarily a matter of leadership development (Lindenhall \& Hammoura, 2015: 7). Succession planning provides a strategy to capitalize on organizational knowledge that would be lost due to retirement, promotion, and general attrition (Helton\&Jackson, 2007:336). He described succession planning as a proactive attempt to ensure that the organization's leaders will be continuous by knowing how those sites will be occupied, whether

347 
planned or unplanned when there are departures for the organization (Schmalzried \& Fallon, 2007:169). The main feature of succession planning in the organization is the active development of talent in the future which is vital to attract and retain the best and most important employees who are likely to be chosen as an alternative to those who leave and who will help today and more for the future growth of the organization (Dauda, 2013: 60).

\section{3-3 Succession planning Goals}

A set of specific goals for succession planning that organizations seek to achieve can be defined. Armstrong has stated that one of the goals of succession planning is to identify successors who are prepared to occupy a higher position, and also clarified the value of succession planning and the selection of the leadership elite as it enables the organization to achieve some goals such as : (Armstrong, 2012: 261)

A- Focus on development

B- Defining the critical or essential roles

C- Establish transparent systems for succession management

$\mathrm{W}$ - Measuring the progress process regularly

C- Ensure flexibility

Noe and others indicated that among the objectives of succession planning are: (Noe, et al., 2018: 258)

A- Regularly and deliberately review the organization's leadership talents by senior management.

B- Ensure the provision of high-level management talents.

C- Providing a set of development experiences that managers must complete in order for them to be taken into consideration in senior management positions, and therefore the organization does not promote managers before they are ready.

W- It aims to attract and retain ambitious administrative employees by providing them with development opportunities.

And we can identified the most important objectives of implementing the succession planning process, which are: (Folkers, 2008: 36-37)

A- Ensuring continuity of knowledge capital.
B- Increasing the number of leaders who are ready to assume positions.

C- Contributing to achieving the strategic mission of the organization.

\section{3-4 Successful succession planning process requirements}

Succession is an event that faces all the work of the organization, sooner or later regardless of its size, when the job holder dies or upon retirement, resignation or promotion, succession is an order imposed on the organization (Dyck, et al., 2002: 144). Consequently, succession planning should take the highest priority within organizations in order to avoid a situation of "fall", which is a common occurrence, in the case of career succession, transfer of knowledge is a critical aspect in view of the organization's continuity as the knowledge of the job holder may be a source of competitive advantage and therefore the departure of any of them It can lead to the loss of an important component of an organization's success, and this means that the organization's human capital stock will be at risk (Durst \& Wilhelm, 2012: 693). It can be identified three different types of knowledge required for succession, which were classified into $\mathrm{K} 1, \mathrm{~K} 2$, and K3 are shown as follows: (Sambrook, 2005: 588)

A- (K1) includes technical knowledge and process efficiency, and this knowledge can easily be codified and transferred.

B- (K2) includes knowledge about the organization and how it works, and this knowledge can relatively easily be made clear and then transferred to potential successors.

C- (K3) covers the specific implicit knowledge related to leadership, decision-making, risk, etc., it is difficult to make it more apparent and its transmission depends on the willingness of the present person and his ability to share this knowledge.

The key to future success is when assessing and understanding the value of the human resources you possess today and the resources that you will likely need in the coming years, as the future performance of any organization depends on the accuracy and activity of succession planning today, and that careful 
(IJRSSH) 2020, Vol. No. 10, Issue No. III, Jul-Sep

planning also means that the workforce that you have You will be less disruptive and disruptive. In short, improving the value and viability of the future
e-ISSN: 2249-4642, p-ISSN: 2454-4671

depends on planning and building the next generation of human resources (Seymour, 2008: 5).

\section{4 - DATA ANALYSIS :}

For the purposes of achieving the goals of scientific research and ensuring the confidentiality of the evaluation process, the names of employees nominated for future leadership positions are coded. The results of the evaluation of the candidates have been analyzed as shown in the following tables:

Table (1) the results of the evaluation of the candidates of the Administrative, Financial and Legal Affairs Department, according to the two axes : performance evaluation and traits/ job behaviorevaluation

\begin{tabular}{|c|c|c|c|c|c|}
\hline Elements of evaluation & a1 & a2 & a3 & a4 & a5 \\
\hline result of ( performance) evaluation & $\% 76.85$ & $\% 76.25$ & $\% 74.7$ & $\% 72.95$ & $\% 79.2$ \\
\hline Performance gap & $\% 23.15$ & $\% 23.75$ & $\% 25.3$ & $\% 27.05$ & $\% 20.8$ \\
\hline $\begin{array}{l}\text { result of (traits/ job behavior) } \\
\text { evaluation }\end{array}$ & $\% 78.5$ & $\% 74.7$ & $\% 84.15$ & $\% 77.9$ & $\% 79$ \\
\hline (traits/ job behavior)gap & $\% 21.5$ & $\% 25.3$ & $\% 15.85$ & $\% 22.1$ & $\% 21$ \\
\hline $\begin{array}{l}\text { Average rating of the Two axes } \\
\text { (performance) and (traits/ job } \\
\text { behavior) evaluation for the } \\
\text { candidate }\end{array}$ & $\% 77.675$ & $\% 75.475$ & $\% 79.425$ & $\% 75.425$ & $\% 79.1$ \\
\hline
\end{tabular}

Table (2) the results of the evaluation of the candidates of the Planning and Resource Development Department, according to the two axes : performance evaluation and traits/ job behaviorevaluation

\begin{tabular}{|c|c|c|c|c|}
\hline $\mathrm{C}_{\text {Elements of evaluation }}^{\text {Candidate Code }}$ & b1 & b2 & b3 & b4 \\
\hline result of( performance) evaluation & $\% 96$ & $\% 93.25$ & $\% 82.75$ & $\% 76.75$ \\
\hline Performance gap & $\% 4$ & $\% 6.75$ & $\% 17.25$ & $\% 23.25$ \\
\hline result of (traits/ job behavior) evaluation & $\% 97.25$ & $\% 95.5$ & $\% 85.5$ & $\% 83.5$ \\
\hline (traits/ job behavior)gap & $\% 2.75$ & $\% 4.5$ & $\% 14.5$ & $\% 16.5$ \\
\hline
\end{tabular}




\begin{tabular}{|l||c||c||c||c||}
\hline $\begin{array}{l}\text { Average rating of the Two axes } \\
\text { (performance) and (traits/ job behavior) }\end{array}$ & $\% 96.625$ & $\% 94.375$ & $\% 84.125$ & $\% 80.125$ \\
evaluation for the candidate & & & \\
\hline
\end{tabular}

Table (3) the results of the evaluation of the candidates of the Inspection and Investigation Department, according to the two axes : performance evaluation and traits/ job behaviorevaluation

\begin{tabular}{|c|c|c|c|c|}
\hline Elements of evaluation & c1 & c2 & c3 & c4 \\
\hline result of ( performance) evaluation & $\% 70$ & $\% 72.85$ & \%78.4 & $\% 88.45$ \\
\hline Performance gap & $\% 30$ & $\% 27.15$ & $\% 21.6$ & $\% 11.55$ \\
\hline result of (traits/ job behavior) evaluation & \%70.2 & \%71.5 & \%81.55 & $\% 87.15$ \\
\hline (traits/ job behavior)gap & $\% 29.8$ & $\% 28.5$ & $\% 18.45$ & $\% 12.85$ \\
\hline $\begin{array}{l}\text { Average rating of the Two axes } \\
\text { (performance) and (traits/ job behavior) } \\
\text { evaluation for the candidate }\end{array}$ & $\% 70.1$ & $\% 72.175$ & $\% 79.975$ & $\% 87.8$ \\
\hline
\end{tabular}

Table (4) the results of the evaluation of the candidates of the Internal audit and control Department, according to the two axes : performance evaluation and traits/ job behaviorevaluation

\begin{tabular}{|c|c|c|c|}
\hline Candidate Code & $\overline{d 11}$ & $\overline{d 2}$ & $\bar{d} \mathbf{d 3}$ \\
\hline result of ( performance) evaluation & $\% 82.25$ & $\% 76.25$ & $\% 74.25$ \\
\hline Performance gap & $\% 17.75$ & $\% 23.75$ & $\% 25.75$ \\
\hline result of (traits/ job behavior) evaluation & $\% 84.5$ & $\% 71.75$ & $\% 82.5$ \\
\hline (traits/ job behavior)gap & $\% 15.5$ & $\% 28.25$ & $\% 17.5$ \\
\hline $\begin{array}{l}\text { Average rating of the Two axes (performance) } \\
\text { and (traits/ job behavior) evaluation for the } \\
\text { candidate }\end{array}$ & $\% 83.375$ & $\% 74$ & \%78.375 \\
\hline
\end{tabular}


Table (5) the results of the evaluation of the candidates of the Department of Pharmacy and Medical Supplies, according to the two axes : performance evaluation and traits/ job behaviorevaluation

\begin{tabular}{|c|c|c|c|}
\hline $\mathrm{C}_{\text {Elements of evaluation }}^{\text {Candidate Code }}$ & e1 & e2 & e3 \\
\hline result of ( performance) evaluation & $\% 70.95$ & $\% 81$ & $\% 79.85$ \\
\hline Performance gap & $\% 29.05$ & $\% 19$ & $\% 20.15$ \\
\hline result of (traits/ job behavior) evaluation & $\% 71.6$ & $\% 82.35$ & $\% 70.35$ \\
\hline (traits/ job behavior)gap & $\% 28.4$ & $\% 17.65$ & $\% 29.65$ \\
\hline $\begin{array}{l}\text { Average rating of the Two axes (performance) } \\
\text { and (traits/ job behavior) evaluation for the } \\
\text { candidate }\end{array}$ & $\% 71.275$ & $\% 81.675$ & $\% 75.1$ \\
\hline
\end{tabular}

Table (6) the results of the evaluation of the candidates of theDepartment of Technical matters, according to the two axes : performance evaluation and traits/ job behaviorevaluation

\begin{tabular}{|c|c|c|c|}
\hline Candidate Code & f1 & $\mathbf{f 2}$ & f3 \\
\hline result of ( performance) evaluation & $\% 81.5$ & $\% 74.75$ & $\% 82$ \\
\hline Performance gap & $\% 18.5$ & $\% 25.25$ & $\% 18$ \\
\hline result of (traits/ job behavior) evaluation & $\% 72.25$ & $\% 72.25$ & $\% 75.75$ \\
\hline (traits/ job behavior)gap & $\% 27.75$ & $\% 27.75$ & $\% 24.25$ \\
\hline $\begin{array}{l}\text { Average rating of the Two axes (performance) } \\
\text { and (traits/ job behavior) evaluation for the } \\
\text { candidate }\end{array}$ & $\% 76.875$ & $\% 73.5$ & $\% 78.875$ \\
\hline
\end{tabular}

Table (7) the results of the evaluation of the candidates of theMedical Operations and Specialized Services Department, according to the two axes : performance evaluation and traits/ job behaviorevaluation

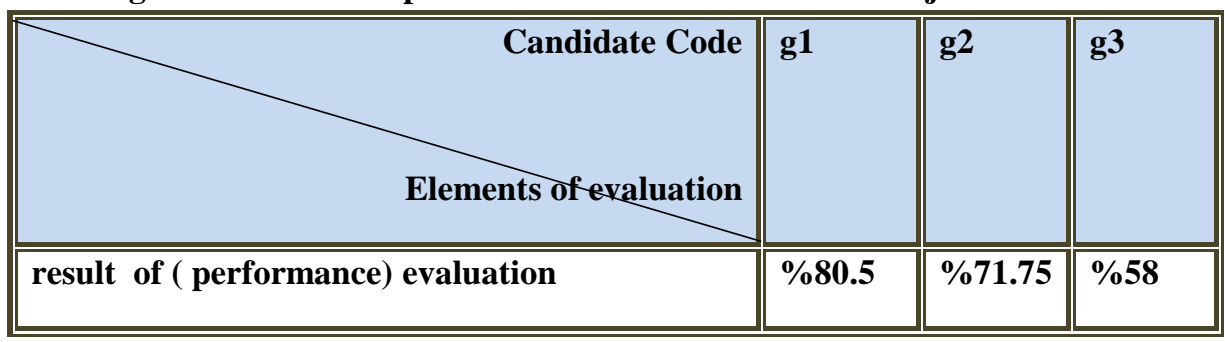




\begin{tabular}{|l||c||c||c||}
\hline Performance gap & $\% 19.5$ & $\% 28.25$ & $\% 42$ \\
\hline \hline result of (traits/ job behavior) evaluation & $\% 79.5$ & $\% 83.75$ & $\% 63$ \\
\hline \hline (traits/ job behavior)gap & $\% 20.5$ & $\% 16.25$ & $\% 37$ \\
\hline \hline $\begin{array}{l}\text { Average rating of the Two axes (performance) } \\
\text { and (traits/ job behavior) evaluation for the } \\
\text { candidate }\end{array}$ & $\% 80$ & $\% 77.75$ & $\% 60.5$ \\
\hline
\end{tabular}

Table (8) the results of the evaluation of the candidates of the Engineering and Maintenance Department, according to the two axes : performance evaluation and traits/ job behaviorevaluation

\begin{tabular}{|c|c|c|c|c|}
\hline $\mathrm{C}_{\text {Elements of evaluation }}^{\text {Candidate Code }}$ & h1 & h2 & h3 & h4 \\
\hline result of ( performance) evaluation & $\% 81.45$ & $\% 74.75$ & $\% 68.4$ & $\% 78.25$ \\
\hline Performance gap & $\% 18.55$ & $\% 25.25$ & $\% 31.6$ & $\% 21.75$ \\
\hline result of (traits/ job behavior) evaluation & $\% 78.05$ & $\% 78.7$ & $\% 75.9$ & $\% 70.7$ \\
\hline (traits/ job behavior)gap & $\% 21.95$ & $\% 21.3$ & $\% 24.1$ & $\% 29.3$ \\
\hline $\begin{array}{l}\text { Average rating of the Two axes (performance) } \\
\text { and (traits/ job behavior) evaluation for the } \\
\text { candidate }\end{array}$ & $\% 79.75$ & $\% 76.725$ & $\% 72.15$ & $\% 74.475$ \\
\hline
\end{tabular}

\section{4-1The general orientation of departments candidates in the General Administration / Medical City Department}

For the purpose of knowing the general trend about the availability of candidates to manage departments in the General Administration of the City of Medicine and their readiness to manage these departments, all candidates were distributed according to the matrix (traits- performance) as shown in Figure (1) 


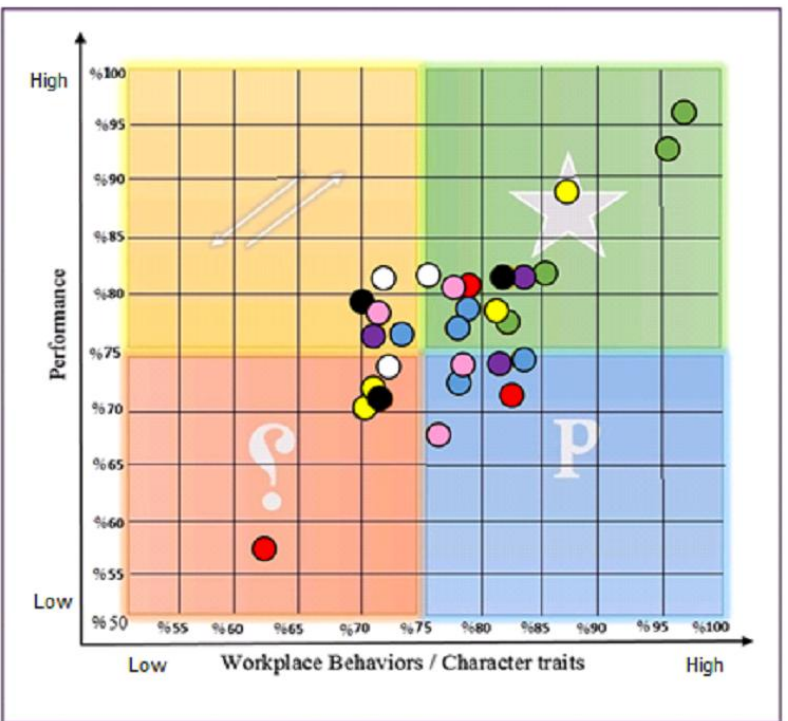

Figure (1) The general orientation of departments candidates in the General Administration / Medical City Department according to (traits - Performance) Matrix As a specific color was assigned to each section, as follows:

\begin{tabular}{|r|r|}
\hline Administrative, Financial and Legal Affairs Department \\
\hline Planning and Resource Development Department \\
\hline Inspection and Investigation Department \\
Internal audit and control Department \\
Department of Pharmacy and Medical Supplies \\
\hline Medical Operations and Specialized Services Department \\
\hline Engineering and Maintenance Department \\
\hline
\end{tabular}

\section{4-2 The Suggested succession planning model to be applied in the Medical City Department}

Based on personal interviews and observations recorded by the two researchers during field coexistence, which it became apparent that there is no model for succession planning for leadership positions or major or critical jobs in the city of medicine, the researchers suggested applying a succession planning model consisting of eight basic stages based on a matrix (traits - Performance) as follows:

Step1 : Determine important positions and jobs (leadership, key, or critical jobs ) in the organization

Step 2 : Preparing a form for evaluating candidates for leadership positions and main or critical jobs according to two axes : (performance evaluation) and (traits/ job behavior evaluation) .

Step 3 : Nomination of the best available employees and their evaluation by their line manager according to the mentioned evaluation form in a neutral, objective and transparent manner.

Step 4 : Analyzing the evaluation forms of the candidates to know the results of the evaluation of the candidates and their functional gaps. 
Step 5 : Distributing the candidates according to the results of the evaluation inside the matrix (traits- performance) to know the extent of the readiness and willingness of the candidates to assume the positions and positions they were nominated in the future, through their presence inside the cells of the matrix, as shown in Figure (2).

Step 6 : Determine the best candidates for succession through obtaining the highest evaluation levels, and the candidate who is present in the Stars Cell or the upper right side of the matrix is preferred.

Step 7 : Setting suitable proposals to address job gaps ( performance gap) and (trait /job behavior gaps) for each candidate based on the results of the evaluation of the candidates and their locations within the matrix for the purpose of preparing candidates to fill the positions and positions to which they are nominated in the future efficiently and effectively.

Step 8 : Monitoring and evaluation.

Figure (3) illustrates the stages of applying the proposed succession planning model to the Medical City

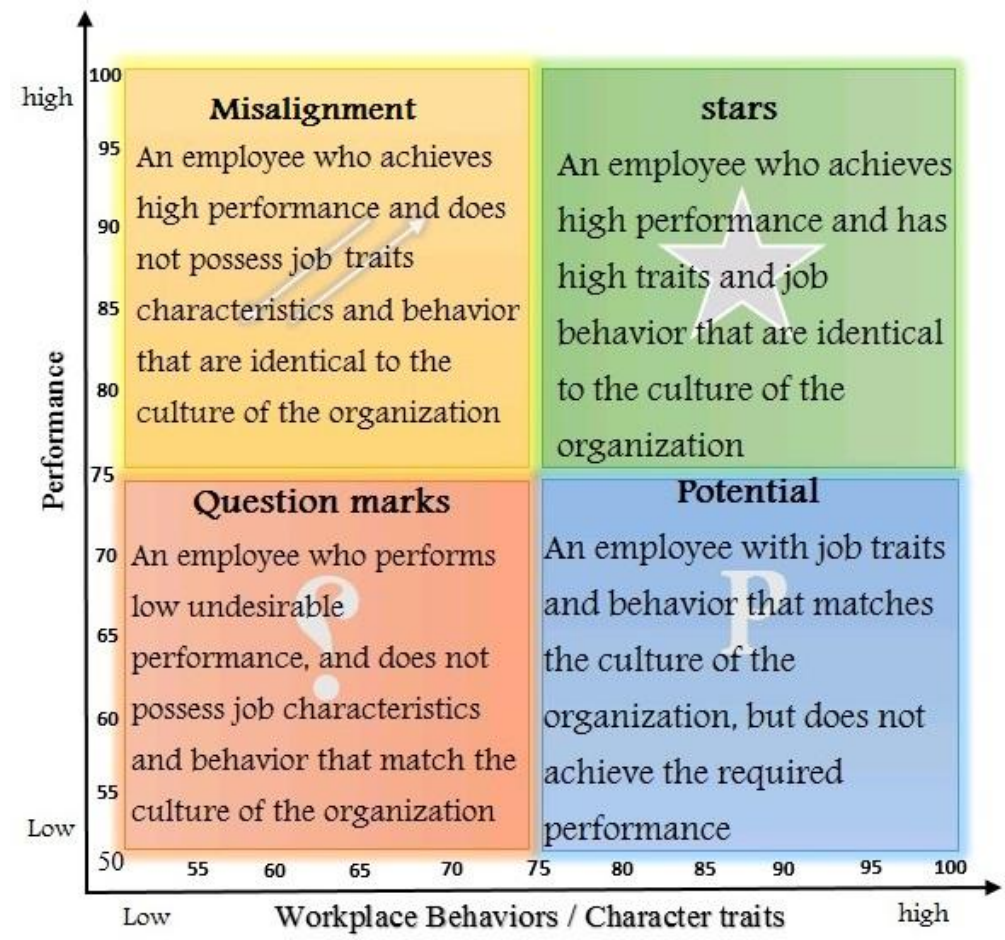

Figure (2)Matrix (traits- Performance) to show the readiness and willingness of candidates for succession 
1 - Identify important positions and functions in the organization

2- Preparing a form for evaluating candidates according to two axes : (performance evaluation) and (traits/ job behavior evaluation)

3- Nomination of the best available employees

4- Analyzing the evaluation forms of the candidates

5- Distributing the candidates according to the results of the evaluation inside the matrix (traits- performance)

6- Determine the best candidates for succession by choosit. employees who approach the top right side of the matrix or present in the Stars Cell

7- setting suitable proposals to address job gaps for each candidate

8- - Monitoring and evaluation

Figure (3)The stages of applying the Suggested succession planning model to the Medical City Department

\section{5 - CONCLUSIONS :}

a- The absence of succession planning programs that explain how to occupy leadership, key, and critical positions in anticipation of any emergency event in the medical city.

b - The leadership positions and the main vacant positions are filled in the event of an emergency by the higher management based on personal criteria by selecting the best available employees according to the opinion of the higher management, and not according to the employee's high capabilities and his leadership and professional competence based on evaluation results Objectivity.

c- The organization possesses employees who have high job capabilities that qualify them to occupy the leading and vacant positions in the future after training them for a purpose to fill their job gaps.

d - The possibility of applying the suggested succession planning model in this organization, according to the results of the opinion poll, according to the opinions of a sample of middle management managers.

\section{REFERENCES}

1. Adewale, O. O., Abolaji, A. J., \& Kolade, O. J. (2011), "Succession planning and organizational survival: Empirical study on Nigerian private tertiary institutions" , Serbian Journal of Management, 6(2), 231-246. 
2. Armstrong, M. (2012), Armstrong's handbook of human resource management practice.12 ${ }^{\text {th }}$ Edition, Kogan Page, Philadelphia .

3. Al-Samman, Eyad (2012), "Succession Planning: Should it Focus Only on the Top Level of Management or Should it be Expanded to the Middle Level of Management as Well?", Master's Thesis in Business Administration, Open University Malaysia (OUM).

4. Barnett, R., \& Davis, S. (2008), "Creating greater success in succession planning. Advances in developing human resources", 10(5), 721-739.

5. Collins, S. K., \& Collins, K. S. (2007),"Changing workforce demographics necessitates succession planning in health care", The health care manager, 26(4), 318-325.

6. Dauda, A. (2013), "Business continuity and challenge of succession in Nigeria: What happens when the CEO leaves", Journal of Business and Management, 8(4), 59-65.

7. Durst, Susanne \&Wilhelm , Stefan (2012), "knowledge management and succession planning in SMEs" , journal of knowledge management, vol. 16 issue:4, pp.637-649.

8. Dyck, B., Mauws, M., Starke, F.A. and Mischke, G.A. (2002), "Passing the baton: the importance of sequence, timing, technique and communication in executive succession", Journal of Business Venturing, Vol. 17 No. 2, pp. 143-62.

9. Folkers, D. R. (2008), "Succession planning and management in Nebraska state government: Perceptions, experiences, and barriers",A Dissertation Presented in Partial Fulfillment of the Requirements for the Degree Doctor of management in organaizational leadership , University of Phoenix.

10. Galbraith, Q., Smith, S. D., \& Walker, B. (2011), "A case for succession planning: How academic libraries are responding to the need to prepare future leaders", Library management, 33(4/5), 221-240.

11. Helton, K. A., \& Jackson, R. D. (2007), "Navigating Pennsylvania's dynamic workforce: Succession planning in a complex environment", Public Personnel Management, 36(4), 335-347.

12. Hickey, Will. (2002), "A Survey of MNC Succession Planning Effectiviness in China", Performance Improvement Quarterly, 15(4), 5-22.

13. Lindenhall, I., \& Hammoura, S. (2015), "Becoming a'high potential'by developing high potential talents: How firms in Sweden employ succession planning and talent management to retain Millennials", Master's Thesis in Business Administration, Jönköping International Business School , Jönköping University .

14. Mondy, R., \& Martocchio, J. J. (2016), Human resource management . $14^{\text {th }}$ Edition, Global Edition, Pearson.

15. Noe, R. A., Hollenbeck, J. R., Gerhart, B. A., \& Wright, P. M. (2018). Fundamentals of human resource management. $7^{\text {th }}$ Edition, McGraw-Hill Education, New York .

16. Romanowski , Dallas(2016), Performance Culture - Drive Profits \& Create a Great Workplace , Create Space Independent Publishing Platform ,California.

17. Sambrook, S. (2005), "Exploring succession planning in small, growing firms. Journal of small business and enterprise development", 12(4), 579-594.

18. Schmalzried, H., \& Fallon, L. F. (2007), Succession planning for local health department top executives: reducing risk to communities. Journal of Community Health, 32(3), 169-180.

19. Seymour, S.(2008),"Boost your business value with succession planning", Human resource management international digest,16(4), 3-5 . 